\title{
Is God a person? Maimonides, Crescas, and beyond
}

\author{
Samuel Lebens \\ Department of Philosophy, University of Haifa, Abba Khoushy Ave 199, Haifa, 3498838, Israel \\ Corresponding author: Samuel Lebens, email: slebens@univ.haifa.ac.il
}

\begin{abstract}
Drawing from multiple generations of Jewish philosophy (from Maimonides until today), this article argues for the seemingly paradoxical conclusion that God is both fully, and not at all, a person. The apparent contradiction in this conclusion is resolved by appeal to a two-layered ontology.
\end{abstract}

Keywords: Maimonides; Crescas; Hassidism; Open Theism; Heschel

In this article I advance a seemingly paradoxical claim, drawn from the Jewish tradition, according to which God is both fully, and not at all, a person. I begin with a working definition of personhood. In the next sections, I explore some Jewish medieval theology, according to which God, on our definition of personhood, is not a person. I then go on to raise objections against this medieval impersonalism, resulting in (a provisional) positive answer to our question: God is a person. But then I develop a number of problems that arise from this new account. This journey finally results in my peculiar conclusion that God is both fully, and not at all, a person; a claim rendered coherent on the adoption of a Hassidic ontology.

\section{Personhood}

When Rabbi A. J. Heschel describes God in personal terms, he talks about God's logos, pathos, and ethos. ${ }^{1}$ He uses these terms somewhat idiosyncratically. Imposing some order upon his terminology, I define these terms as follows:

- A being possesses logos so long as it has a set of beliefs with non-normative content (that is to say, non-prescriptive content describing non-moral states of affairs).

- A being possess pathos if there is something that it feels like to be that being, and if that feeling has an emotional valence.

- A being has an ethos so long as it has a set of beliefs with normative content.

Inspired by Rabbi Heschel, I argue that personhood combines logos, pathos, and ethos. Moreover, a being cannot be a person without possessing these properties reflectively so that it should be aware that it has them. In what follows, I shall demonstrate that this conception of personhood captures the essence of personhood as that concept has appeared in the history of Western Philosophy. 
According to Aristotle, the capacity for 'intellectual perception' is what makes a person a person. To see that $1+1=2$, we don't need to use our eyes. Our intellects simply perceive, without the mediation of sense organs, that it's true. This, he claims, is the faculty that separates us from non-persons. ${ }^{2}$ Thus began the association between personhood and logos.

John Locke defines a person as, 'a thinking intelligent being that has reason and reflection and can consider itself as itself, the same thinking thing, in different times and places' (Locke, 1997, II.xxvii.9, p. 302). In other words: self-consciousness extended over time by means of memory, stretching into the past, and anticipation, stretching into the future, is what binds the various temporal stages of a person together. This helped Locke to answer questions of personal identity over time. But as we shall see, the person's temporal consciousness is key to what makes a person a philosophically significant being to begin with. Moreover, from Locke we inherit the notion that only if a being is conscious of possessing the (other) key characteristics of personhood can it be considered a person.

According to many systems of ethics, the possession of desires and preferences, even though non-persons can have them too, will be an essential ingredient for the creation of the special ethical significance of persons. To illustrate this claim, consider the status of persons for utilitarianism, for Kantian ethics, and for virtue ethics.

Utilitarianism: All sorts of animals have desires and preferences, but given their temporally extended self-consciousness, only persons can have future-oriented desires. ${ }^{3}$ Consequently, only persons can suffer the disutility of thwarted expectations or futureoriented anxiety. Only persons have the capacity to suffer from the possession of painful memories. Consequently, utilitarians, whose ethical universe recognizes only pain and pleasure, will accept that persons are worthy of special ethical consideration (Singer (1993), 90-91).

Kantian ethics: For a Kantian, a person should never be treated as a means, but always, at the same time, as an end (Kant (1998), Ak: 4.429, p. 38). It is the possession of a free will that bestows this significance upon her, but the possession of a will requires the possession of preferences.

A self-driving car manifests purpose. It purposefully directs its motion towards its predetermined location, while avoiding obstacles en route. According to Kant, the extra ingredient required to transform this sort of purpose into a will is self-consciousness (Ibid., Ak: 4.449 , p. 54). This is what self-driving cars lack. This requires a representation of oneself as an 'I' (Kant (2010), Ak: 7.127, p. 239).

But, according to Christine Korsgaard, what really makes a person an end in herself is that only a person can face 'the problem of the normative'. This is the problem that emerges when we recognize that there may be a tension between what we want and what would be right (Korsgaard (1996), 93). The potential for tension between a person's emotional drives and her faculty of reason is part of what makes her a self-legislating being, a source of her own normativity, an end in herself. ${ }^{4}$ Self-driving cars can have no internal conflicts for a rational will to overcome.

Virtue ethics: According to virtue ethics, the moral life concerns acting virtuously and cultivating virtues. Acting virtuously is about doing virtuous deeds. Cultivating virtues is about creating the disposition to perform such deeds when called upon. And thus, the inner life of the agent seems to have no role to play in the moral universe. Rosalind Hursthouse begs to differ.

Suppose that a person (a) performs a virtuous deed, (b) that she knows that the deed she performs is virtuous, and (c) that she acts as she does because she recognizes that it's virtuous (in other words, she doesn't act for ulterior reasons, or under compulsion). But then, imagine that, even though all three of these conditions are met, she performs the virtuous deed 'reluctantly' while someone else 'does the same easily and gladly' 
(Hursthouse (1999), 125). In such cases, she argues, the virtue ethicist "may have to admit that the agent with the inappropriate feelings "acts morally" and acts (fairly) well, but we can insist that the agent with the appropriate feelings acts better' (ibid.).

In other words, virtue ethics requires that people perform virtuous deeds, but (ideally) it also requires that they perform them virtuously. This latter requirement demands an inner life of moral motivation. It is the possession of such an inner life (one that can be refined over time, or left to deteriorate) that makes people members of the ethical universe.

Moreover, as Hursthouse points out, 'The virtues (and vices) are all dispositions not only to act, but to feel emotions, as reactions as well as impulses to action. (Aristotle says again and again that the virtues are concerned with actions and feelings.)' (ibid., 108). Moreover, dispositions are, by definition, temporally extended (Shoemaker (2015), 437), and thus the possession of temporally extended emotions, preferences, and desires is a central ingredient of what makes people ethically significant, either because they play a role in making us ethical agents (for the Kantian and the virtue ethicist), or because they make us worthy of special consideration (for the Kantian and the utilitarian), or both.

Accordingly, Rabbi Heschel was right to think of personhood in terms of the reflective possession of (1) logos, (2) pathos, and (3) ethos. The only problem with this account is that it doesn't capture the inherently social nature of personhood. It captures personality without capturing inter-personality. To that extent it remains incomplete.

How does a being open itself up to interpersonal relations? Dan Zahavi (2015) distinguishes between three states: (1) emotional contagion; (2) empathy; and (3) shared emotion. The third, he suggests, is the key to deep interpersonal interaction. You cannot experience another person in a distinctively second-personal way (as a you instead of an it) if you cannot share emotion with them. Moreover, you cannot view another as a potential collaborator, for the construction and maintenance of social institutions (in ways described, for instance, by John Searle (1990, 414; Idem (1995)), if you cannot view other people in a second-personal way.

So, what is shared emotion, and how does it differ from contagion and empathy?

Imagine that you walk into a football stadium. You feel swept away by the euphoria of the crowd. Your euphoria will not be shared with individual members of the crowd; "you might not even be aware of the others as distinct individuals' (Zahavi (2015), 87). Their happiness just rubs off on you. That's emotional contagion.

Contagion must 'be distinguished from empathy, since the latter involves a focus on and an awareness of the other' (ibid.). Indeed, empathy is 'a form of other-directed intentionality, which allows foreign experiences to disclose themselves as foreign rather than as one's own' (ibid., 88). Mirror neurons are apparently responsible for generating the sensation that, when empathizing with another, you have something like direct access to their emotional state. The autistic person, by contrast, who we now know to suffer from decreased mirror neuron activity (Ramachandran and Oberman (2006)), often has to conclude that someone is happy by inference. They don't tend to have this sense of direct access to the states of another.

Emotional sharing goes one step further than empathy. Emotional sharing is more than two people having the same emotion concurrently. It is more than two people being aware of concurrently experiencing the same emotion. Rather, the emotion itself is structured and qualified, for each person, by the awareness that the emotion is shared. For example:

[A] couple is enjoying a movie together. Not only do they each perceive and enjoy the movie, but they also experience that the other is attending to and enjoying the movie 
which is something that affects the structure and quality of their own enjoyment.... We are dealing with emotional experiences that ... are co-regulated and constitutively interdependent.

(Zahavi (2015), 90)

Emotional sharing has a lot in common with the phenomenon of joint attention, so much so that the former is probably a prerequisite for the latter:

For joint attention to occur, the attentional focus of two (or more) persons shouldn't merely run in parallel; it must involve an awareness of attending together, that is, the fact that both persons are attending to the same object must, to use Sperber and Wilson's (1986) phrase, be 'mutually manifest'. This is precisely what makes joint attention quite unlike any kind of experience one might have on one's own.

(ibid., 91)

Joint attention isn't merely two people attending to the same thing at the same time. It's two people experiencing the world in ways that are 'co-regulated' and 'interdependent'. Most cases of joint attention in the literature focus on triangulation - two or more people focusing on some third object, external to them both. But the first experiences of joint attention tend to occur without triangulation, directly between baby and caregiver (Rochat and Striano (1999); Rochat (2014)).

Indeed, it has been suggested that infants come to learn about the social world, not 'from "he's" or "she's" whom they observe dispassionately from the outside' but "from "you's" with whom they interact and engage in collaborative activities with joint goals and shared attention' (Moll and Meltzoff, 2012, p. 398).

(Zahavi (2015), 92)

To the extent that this capacity underlies collective intentionality, and to the extent that collective intentionality is what lies at the foundation of our most complex social structures, as communal and social beings, we are clearly talking about some of the faculties that set persons (be they human or dolphin or what have you) apart from non-persons. To the extent that a person cannot enter interpersonal relationships, their personhood must surely be impaired.

If God is a person, I assume that His personhood isn't impaired (given His perfection). Therefore, when I ask whether God is a person, I want to know whether He satisfies four criteria: the reflective possession of (1) logos, (2) pathos, and (3) ethos, in addition to (4) the capacity to engage in joint attention (a capacity which sustains interpersonal relations). So, is God a person?

\section{Maimonides}

According to Maimonides, what we would call personhood only really emerges after 'the fall of man'. Before they ate from the tree of knowledge of good and bad, Adam and Eve were - according to Maimonides - purely rational, characterized exclusively in terms of logos. The ultimate values of logos are truth and falsehood. To eat from the tree was, therefore, to be introduced to the hitherto alien world of pathos, with its entirely new values of good and bad; desirable and ugly (Maimonides (2000), 1.2).

As Lawrence Berman $(1980,8)$ summarizes: 
The fall of man consisted in a change of priorities, from an interest in the things of the mind to becoming interested in the things of the body; from being a philosopher, a master of his passions, to becoming a beast in human form, mastered by his passions ...

But we should ask: are the categories of good and evil really so far removed from logos, and from truth? Are there no moral truths? Is morality, for Maimonides, nothing more than a question of postlapsarian convention, a consequence of the descent into the passions?

Some scholars conclude that Maimonides must indeed have been an ethical noncognitivist (e.g. Fox (1990), 181). But if prelapsarian man had no knowledge of ethics, how could he have known that it was wrong to disobey God's commandment? How could he be held responsible? Moreover, as Rabbi Soloveitchik noted:

It is almost unthinkable that Maimonides, the great student of Halakha [Jewish law] who in the Mishne Torah [his code of Jewish law] placed so much emphasis on the ethical gesture, should have, in the manner of Aristotle, demoted that gesture to mere opinion.

(Soloveitchik (2016), 123)

In fact, neither Maimonides nor Aristotle can fairly be labelled non-cognitivists, nor can they be accused of demoting ethics to mere opinion. Like Aristotle, Maimonides thought that ethics could never be a full-fledged science. This is because the ethicist must respond to the contingent features of the human situations in which we find ourselves. Ethical reasoning must therefore be guided, in part, by consensus and convention rather than the $a$ priori proofs of a purely theoretical science (see Aristotle (2009), I.3, p. 4).

But Aristotle doesn't deny that there are ethical facts. Moreover, Aristotle accepts that some general ethical principles can be known a priori. For example, Aristotle might consider it a demonstrable, analytic, a priori truth that ethics aims towards the achievement of human flourishing. But, since each human is different, it will be a contingent matter what best achieves that aim in any given situation. Accordingly, ethics cannot be a general science.

Similarly, Maimonides defines a good action as one directed towards a 'noble end' (Maimonides (2000), 3:25), and declares that intellectual perfection is the telos of the human being (e.g., ibid., 1:1). Far from ethical non-cognitivism, what emerges is a strident consequentialism: good actions promote the intellectual perfection of their agents (or, perhaps, the net intellectual perfection of humanity). Anything that gets in the way of this aim is, objectively, bad (Harvey (1986), 134).

At this point, Maimonides appeals to something alien to Aristotle - revelation. As Daniel Rynhold (2021) explains, God revealed to the Jewish people, in the form of the Torah:

the best possible [system of rules] for the achievement of our ultimate perfection from a rule-consequentialist perspective, and general adherence to the rules will inculcate in humanity the necessary virtues to enable social, political, and in the best case, intellectual perfection.

Even the Divine law cannot trade in demonstrable truths. Its moral proclamations, in any given instance, cannot be demonstrated a priori. As Maimonides acknowledges (Maimonides (2000), 3:34), and Rynhold (2021) summarizes, 'God can only deliver rules that will, in the long run, and for the most part, achieve [intellectual] perfection.' 
When Maimonides distinguishes between truth and falsehood on one side, and good and bad on the other, he doesn't mean there are no ethical truths. Rather, the scientific mindset - which pursues only a priori investigations - can discover only their most general contours. Those general ethical facts fall on the truth-falsehood side of the distinction. But the detailed prescriptions of an ethical system, by contrast, fall on the other side. Those prescriptions were largely irrelevant to prelapsarian humans. They had very little need for the categories of good and bad, beyond the very general ethical truths that they could discover a priori. Then came the fall of man, a descent into the world of pathos, and the temptations of the flesh. This required a padding out of our ethos, applying general ethical truths to a new set of practical questions, with no certain way of discovering the right answers. This was when Adam and Eve descended into personhood.

Prelapsarian humans, by contrast, possessed logos, a purely general ethos, and no pathos. Likewise, the God of Maimonides, to the extent that words can do Him justice, has logos and a purely general ethos. But God, in His perfection, like prelapsarian humans, has no pathos.

But what about the Bible? Doesn't God display emotion in the Bible? Maimonides was committed to the truth of scripture and so felt compelled to read it in ways that respect the findings of a priori philosophy. Even if God really had an emotional life, which, for Maimonides, was out of the question (Maimonides (2000), 1.52, p. 70), we can, at least, know a priori that, irrespective of how the Bible presents Him, the creator of the universe suffers no change in emotional state from situation to situation.

God can't change because change is necessarily a transition from potentiality to actuality. In his fourth argument for the existence of God, Maimonides establishes - along familiar Aristotelian lines - that God is the unmoved mover (ibid., 2.1); the ultimate explanation of change in the cosmos. If He too were subject to change, we would have to appeal to another being to explain that change.

How then should we read the Biblical account of God's dynamic emotions? When the Bible says that 'God has emotion X', it really means that God's causal imprint on the world around us corresponds to the causal imprint that our actions tend to have when we are motivated by X (ibid., 1.54). Given the causal imprint that God leaves on the world, we experience Him as if He experiences changing emotional states.

God doesn't perform multiple actions, each at different times and places; rather, His one timeless action gives rise to various, changing effects in our world. Maimonides compares this to a flame which has different effects on different substances - some it softens, others it hardens, some it darkens, others it lightens, but all the while, the flame just does what it does without change (ibid., I.53).

Likewise, God knows all things, but - according to Maimonides - He knows them all together as a single item of knowledge (ibid., 3.20, p. 291). God doesn't know things by standing related to various discrete facts, say $P, Q$, and $R$. That would be to divide His knowledge. It would also make His knowledge reliant on things outside of Him - namely, $P, Q$, and $R$. Rather, God is thought somehow to know all things in virtue of knowing only Himself.

This theory of Divine knowledge, if coherent, rules out interpersonal relations. God's emotional states cannot be 'constitutively interdependent' upon the states of others. That would render Him a patient undergoing changes in response to them. ${ }^{6}$ Therefore, God cannot experience emotional sharing. God can't even empathize. Empathy requires more than the propositional knowledge that, at time $t$, a given person is experiencing a certain emotion. Empathy requires a direct awareness of another, an unmediated awareness of their emotional state as their emotional state. All of God's knowledge, by contrast, is mediated by God's knowledge of Himself.

That the God of Maimonides lacks empathy doesn't entail that He's callous. As Herbert McCabe points out: the fact that the God of Aquinas (and, Maimonides) cannot suffer with 
His creatures, shouldn't entail that 'God must by nature be unsympathetic, apathetic, indifferent, even callous'. Similarly, the fact that 'God could not be a supporter of Glasgow Celtic' doesn't entail that God is 'a Rangers fan' (McCabe (1985), 466). This God is neither sympathetic nor callous. In fact, this God isn't too distant to be empathetic. Sympathy is a bridge between two persons, and God is too close to require a bridge:

If the creator is the reason for everything that is, there can be no actual being which does not have the creator at its centre holding it in being. In our compassion we, in our feeble way, are seeking to be what God is all the time: united with and within the life of our friend.

(ibid., 469) $)^{7}$

I can see how this line of reasoning might be comforting to the believer in such a God, but we should be under no illusion: this God is not a person. However close He might be to you, He feels nothing.

The God of Maimonides has no pathos, nor can He engage in interpersonal relations. The only thing we share with Him is logos. Indeed, that is all that the Bible means, according to Maimonides, when it says that we were created in God's image (Maimonides (2000), 1.1). Like God, we have the power of intellectual perception. In that sense alone, human nature 'has been compared - though only apparently, not in truth' to the nature of God (ibid.). Note: the likeness is apparent rather than veridical.

According to Maimonides, everything said about God can only be more or less false (including this statement). He arrives at this paradoxical view because of his arguments for God's existence (ibid., 2:1). They demonstrate (if sound) that God is the first cause. This entails that God isn't composite. If God were composed of parts, one could reasonably ask what causes those parts to hold together. That question presupposes, per impossibile, a cause prior to God (ibid., introduction to volume 2, premise 21). Therefore, God must be simple. But whenever you say something about God - given the subject-predicate syntax of language - you make a distinction between God and God's properties. This misrepresents His simplicity (ibid., 1:51). ${ }^{8}$ Moreover, to predicate something of God is to place Him under some species or genus when, as first cause, $\mathrm{He}$ is supposed to be above every genus and species. Hence: everything ever said about God must be more or less false.

Nevertheless, when speaking with the vulgar, Maimonides is, like the Bible, willing to represent God as a rational being. By contrast, he thinks it important to disabuse even the uneducated masses of the belief that God has a body (ibid., 1.35). Talk of God's rationality is more tolerable, even though, strictly speaking, false.

The God of Maimonides is not a person. To the extent that we can say anything about him, we can say - when speaking with the vulgar - that He possesses logos and a general, limited, ethos. That's as far as his theology can go in the direction of divine personhood.

\section{Crescas}

Medieval theology was able to take us further in the direction of divine personhood than Maimonides. Even Maimonides envisages a blissful disembodied afterlife in which only the intellect survives and enjoys an uninterrupted beatific vision. ${ }^{9}$ Accordingly, Maimonides has some notion of a purely intellectual joy. So why can't God experience that joy too? Indeed, a number of classical theists believe that the joy that our disembodied intellects will experience in the beatific vision is God's own joy (Augustine (1972), IX.23, p. 368).

Since God knows all things in virtue of knowing Himself, God is constantly contemplating Himself. Consequently, $\mathrm{He}$ is constantly contemplating completely unqualified 
perfection. The appropriate response to contemplating such perfection is joy; just the sort of intellectual joy that Maimonides promises the righteous in the afterlife (cf. Aquinas (2007), II-II, Q. 28, articles 1-4).

In this way, and even if Maimonides doesn't, the classical theist can make room for an emotion within the mind of God; a constant intellectual joy. Perhaps Maimonides refuses to take this route because intellectual joy, though an appropriate response for creatures to the perfection of God, isn't obviously an appropriate response for God to His own perfection. ${ }^{10}$ Hasdai Crescas also refuses to take this road towards divine emotion, but for different reasons. Indeed, Crescas ends up attributing a much fuller species of joy to God.

First, Crescas rejects the radical apophaticism of Maimonides. God is simple, but that simplicity isn't misrepresented by the syntax of language. God's various attributes hang together so beautifully that He has (at most) one property. ${ }^{11}$ His power, love, goodness, and wisdom are all just aspects of His one indivisible essence (Crescas (2018), 1.3.3, p. 109). Moreover, if a predicate applies to God, it does so not in virtue of God's instantiating some sort of Platonic universal that differs numerically from Him. God's essence doesn't hang above God - God just is what He is essentially; He is His essence. Rather, a predicate applies to God iff God is the perfect exemplar that gives meaning to that predicate. $^{12}$

When we say that something is wise, we mean that it resembles God in respect of God's wisdom. When we say that something is strong, we mean that it resembles God in respect of God's strength. The same is true for any other predicate of perfection. But note:

(1) These resemblances are a matter of degree. The Bible says that God can't be compared to any other being, not because there are no predicates that apply both to God and to His creatures, but because the difference in degree of perfection is always infinite.

(2) The multiple aspects of resemblance don't track multiple properties of God. God is perfectly simple, but His simple essence allows for an infinite amount of logical division into an infinite number of attributes (i.e. modes of resemblance) (ibid., pp. 108, 323). ${ }^{13}$

Crescas allows us to talk about God with fewer qualifications than Maimonides. But, according to Crescas, it would still be wholly inappropriate to predicate intellectual joy of God. That sort of joy would be an appropriate response either to the surprise of discovering a new fact or to overcoming an intellectual obstacle. God never transitions from ignorance to knowledge. He is never surprised. There are no intellectual obstacles in His way (ibid., 1:3:5, p. 117). Instead, God experiences a pure joy, namely the feeling that one has in the act of bestowing love upon others:

[T]here is no love without pleasure in the will - and this alone is true joy. As it is said: 'Let the Lord rejoice in His works,' [Psalms 104:31] which means that the joy is in His works, and it derives from the overflow of His goodness to them in keeping them in constant existence in the most perfect way.

You might think the joy we experience, receiving God's love, would be more intense than the joy that God experiences. Indeed, if we're honest, it's often more exciting to receive a gift than to give one! Crescas insists otherwise. If a predicate applies to God, it does so because God is the perfect exemplar of its meaning. The predicate will apply primarily to God, and only derivitively to mankind. Accordingly, if God experiences joy, our joy is but a pale reflection of that joy; a joy which Crescas - following certain biblical cues 
- goes on to describe in terms of חשק, which corresponds to a passionate, even erotic love (ibid., p. 118).

In this way, Crescas arrives at a theology that preserves the central tenets of classical theism, with its immutable and impassible God, but gets much closer to personalism than Maimonides or even Aquinas. This God doesn't merely have a causal imprint that makes Him look like an emotional being, nor does He enjoy only a rarefied intellectual pleasure. He experiences the constant and intense joy of passionate love.

For Crescas, any negative emotion - any note of suffering - would imply that things aren't right with God; that God is in need. That cannot be. ${ }^{14}$ But note: according to Crescas, God experiences joy with such intensity that all of our emotions would seem positively mild in comparison. What God lacks in terms of emotional range He more than makes up for in terms of emotional depth. Moreover, there exist human persons with severely limited emotional range. That isn't sufficient to disqualify them from being persons, nor must it even impair their personhood.

Think, for example, of people in the midst of accute unipolar depressive episodes. They experience strong emotions, drawing only from a narrow range of feelings. A growing consensus claims that some people suffer from unipolar mania (Makin (2019); Stokes, et al. (2020)): extended episodes of extreme euphoria with little room for any other state. These conditions don't mar the personhood of those who suffer them. In fact, there's a sense in which their personhood is rendered especially salient by their vulnerability. Consequently: Crescas's God shouldn't be excluded from personhood merely because His emotional range is limited.

Without equivocation, the God of Crescas meets three of the necessary conditions for unimpared personhood. He reflectively has logos, pathos, and ethos, but is He open to interpersonal relations?

Classical theists tended to agree that the following three things (at least, in the case of God) are identical: (1) an intellect, (2) its act of intellectual perception, and (3) the thing that the intellect intellectually perceives. Crescas could barely contain his disdain for this view. It entails that every item of knowledge is identical to every other item of knowledge, or it entails that you become a numerically different intellect every time you learn something new (ibid., 2.6.1, p. 213; 4.11, pp. 351-352).

Crescas insists, what God knows is not identical to what God is (ibid., 4.13, p. 354). How could all of the intelligibles be rendered one, and in turn rendered somehow identical to an omniscient God, and to His act of knowledge? Rather, if God knows every particular, then He must know them severally. He cannot be identical to all of them. But how will Crescas avoid the problems that pushed classical theists to their strange position to begin with? How can God's multiple objects of knowledge be rendered consistent with Divine simplicity? How can we block the inference that God is made knowledgeable by the things that He knows, which entails that things outside God are contributing to His perfection, or at least, acting upon God (ibid., 2.1.2, p. 124)?

Crescas responds as follows. Typically, an object is ontologically prior to human knowledge about it. If it didn't exist already, how could we come to know of it? God's knowledge is different. God's knowledge confers existence on the things that it knows (ibid., 2.1.4, p. 139). Humans are perfected (and acted upon) by the things that they know because those things play a role in giving rise to human knowledge, but in the case of divine knowledge, the order of explanation is reversed; God's knowledge gives being to the things that He knows.

As I understand the view, an analogy can be drawn between God's causal activity, and His knowledge. As we discussed above, God can perform just one action that gives rise to a panoply of various effects - like the single flame that causes some things to soften, some to harden, some to get darker, and some lighter. Crescas is, I think, suggesting, analogously, that in one single act of knowledge, God knows every particular. He knows 
them severally, and His knowledge of them is responsible for giving them their being. ${ }^{15}$ The singularity and unity of God's knowledge is secured: in one single glance, God sees all things; directly and severally, without mediation. The things that God knows don't constitute His intellect; that would pollute His simplicity. On the contrary, God is what gives being to the multiple things that He knows. ${ }^{16}$

God's knowledge of the changing states of particulars doesn't imply that God's knowledge undergoes change. This can be guaranteed in multiple ways. One could place God and His knowledge altogether beyond time. ${ }^{17}$ He eternally knows all things (past, present, and future) in His eternal present; a perspective from which God can monitor all of the changes that occur on the timeline, in one single glance, without the need for any succession or change in God Himself. Alternatively, insist that God, even if He exists within time, always knew everything that was ever going to happen (this option is easy for Crescas to adopt since he was anyway committed to determinism). When God's knowledge of future things becomes knowledge of present things, God merely undergoes something analogous to what we would nowadays call a Cambridge change.

You are now reading this article. Yesterday God knew that you would be reading this article today. That knowledge entailed, yesterday, that you would be reading this article today. Right now, He knows that you're reading this article now, which entails that you're reading this article now. Moreover, it's already the case that God will know tomorrow that 'yesterday, you were reading this article'. All that seems to be changing here, from moment to moment, is the tense of what God knows, but nothing fundamental is changing in God Himself (ibid., 2.1.4, p. 140) - hence the analogy to a Cambridge change.

This brings us back to empathy. The God of Crescas can be directly aware of a person and her emotional states. God isn't held at bay from the particulars He knows. His knowledge isn't mediated. God's only emotion may be joy, but He can be directly aware of your sadness, as your sadness, empathizing amidst His joy.

You might say that you cannot empathize with an emotion you've never experienced. But the claim is that God does experience these emotions, but not as His own. It's not that he knows them merely cognitively, through some propositional knowledge. He knows these emotions directly. ${ }^{18}$ Accordingly, He can know what it would feel like to be you, and to feel your emotions as you do, even if He couldn't know what it would feel like to be sad Himself, since the only emotion He can experience as His own is joy. Again, this doesn't mean that God cannot experience other emotions, He just can't experience them as His. ${ }^{19}$ Nevertheless, He has direct epistemic access to the emotional states of others, and thus, He would attain to what Linda Zagzebski (2013) calls omnisubjectivity.

In fact, Crescas presents a challenge to Zagzebski's claim that an impassible God can't be omnisubjective (ibid., 45). Zagzebski there assumes that one can only have direct knowledge of another person's emotions if that person's possession of emotions somehow acts upon you. But, according to Crescas, that assumption doesn't hold for God's knowledge of our emotional states since the standard direction of dependence of knowledge upon the known is reversed in the case of divine knowledge. Our emotions don't act on God's knowledge. Rather, God's knowledge of our emotions is what gives rise to our emotions. Crescas' God is perfectly impassible. Nothing acts upon Him, and yet He is perfectly empathetic.

Empathy is precisely the ability to experience a phenomenal state, but not as your own. You don't have to have had a given emotion to be able to see it in the face of another. In so doing, there's a sense in which you feel it too - but again, not as your own. We know that mirror neurons play a role in facilitating this sort of experience in human brains. For example, reading or listening to a narrative tends to trigger an offline neurological simulation, involving mirror neurons, of witnessing the events described (Young and Saver (2001); Oatley (2008); Marr (2011)), allowing us to empathize with fictional characters in situations very distant from any we've ever witnessed before. 
Admittedly, humans can only simulate experiences that they have the neurological hardware to experience for themselves. We can empathise with emotions that we don't currently experience, and even with emotions that we haven't previously experienced, but we can't empathise with emotions that are impossible for us to feel. Consequently, Ryan Mullins fears that there's a conceptual confusion in thinking that God can understand phenomenal experiences that He's incapable of having for Himself (Mullins (2020), 48).

But consider Tolstoy. Does Tolstoy know what it feels like to be Anna Karenina? I understand why we might say no. He's a man. She's a woman. She can therefore have experiences that he can't have. On the other hand, Tolstoy's knowledge of Anna Karenina (or his act of imagining her) is what brings her and her feelings into existence (to the extent that they exist at all). This might justify the claim that he knows exactly what she feels. Crescas would say the same thing about God, and with more warrant since God's far more cognitively powerful than Tolstoy. ${ }^{20}$

But even if the God of Crescas is empathetic, it takes more than empathy to be fully personal. Deep interpersonal relations require joint attention, which requires the capacity for emotional sharing. This is a step too far for the God of Crescas. He is always an agent and never a patient. When He empathises with you, your emotional states don't act on Him; rather, His knowledge brings you, along with your emotional states, into being. God's own emotional states cannot be 'constitutively interdependent' with those of another (which is required by the definition of emotional sharing).

Crescas' God is possessed of logos, pathos, and ethos. He is so empathetic that $\mathrm{He}$ knows what it feels like to be a person. But He isn't one. He cannot maintain interpersonal relations. The theology of Crescas comes as close to divine personhood as medieval Jewish philosophy ever did, but his God is still not a person. Sadly, impersonalism generates the objections explored in the next section.

\section{Problems with impersonalism}

\section{Objection I}

Impersonalism conflicts with the doctrine of omniscience. ${ }^{21}$ Maimonides, like many other classical theologians, claims that God knows all things only in virtue of knowing Himself. That might work for propositional knowledge. But not all knowledge is propositional.

Consider Frank Jackson's thought experiment about the brilliant neuroscientist, Mary, who - despite growing up in a totally black and white environment - knows every true proposition that a complete neuroscience (and, indeed, a complete physics) could furnish her about the human experience of the colour blue (Jackson, 1982). Given her environment, she can't know what the colour blue looks like. Jackson's point is that knowing everything there is to know about physics isn't to know everything there is to know about the world. There are facts that are not physical facts. But what sort of knowledge of the world does Mary gain?

As Eleonore Stump points out, what Mary learns upon seeing blue for the first time doesn't seem to be merely the truth of a new proposition. Admittedly, she learns the truth of the proposition that 'blue looks like this' (and perhaps other propositions too), but "the "this" here simply gestures toward what she [has come to know]: it does not reduce it to propositional form' (Stump (2012), 51). In other words: 'knowing a color is a candidate for a kind of knowledge that is not' propositional (ibid.); a kind of knowledge that seems to be more intimate and direct than propositional knowledge. If that conclusion is right, then some knowledge cannot be mediated. If all of God's knowledge is mediated, then God's omniscience is threatened.

Crescas can respond. His impersonal God has direct knowledge of facts, and things. He cannot experience certain mental states for Himself, but He can know what they feel like 
for others. Accordingly, there's no phenomenal state that the God of Crescas can't know. Nevertheless, Crescas still struggles to preserve God's omniscience, since there are certain features of the world that are only revealed to an agent when that agent experiences an emotion.

My wife and I visited the house of a man in rural Swaziland, dying of AIDS. The King of Swaziland was building palaces for his fifteen wives but was neglecting infrastructure. This made it impossible for sick people in the countryside to make their way to hospital - road connections were too poor. The Global Fund donated medication to treat a great many HIV patients, but the King levied a tax on them. This man was going to die. His wife had already. His children would be vulnerable orphans in a country where it was widely believed that HIV could be cured by raping a child. Leaving that house, the leader of the tour said that he wanted us to feel angry.

I think he was right. To have a propositional understanding of the ethical contours of this situation, but not to feel anger, would indicate a failure to understand the situation as well as those who did feel angry (cf. Scrutton (2011), 70). Sadness alone would be too close to resignation in the face of a rectifiable injustice. A lack of emotion, at least for a being that is capable of emotion, would amount to cold indifference. Only anger did justice to this reality. The impassible God of Maimonides and Crescas would be insensitive to that facet of reality uncovered by anger.

To the extent that a wide range of emotions (from compassion to anger) can play an indispensable role in uncovering the truth of a situation, a God whose emotional range is limited stands to be intellectually compromised.

\section{Objection 2}

Rabbi Sacks describes an experience, familiar to many devotees of the Abrahamic faiths. 'God', he writes,

is the personal dimension of existence, the 'Thou' beneath the 'It', the 'ought' beyond the 'is', the Self that speaks to self in moments of total disclosure when, opening ourselves to the universe, we find God reaching out to us ... At its height, faith is none other than the transfiguring knowledge that 'Yea, though I walk through the valley of the shadow of death I will fear no evil, for You are with me.'

(Sacks (2000), 84, quoting Psalms 23:4)

Rabbi Sacks is describing a second-personal experience; the sort of experience the Psalmist had, leading him to declare that throughout his trials and tribulations, 'I was always with You. You held my right hand' (Psalms 73:23).

Impersonalists can respond: religious experiences of a personal God are simply deceptive. God manifests as if He has an emotional life but, other than (perhaps) the constant joy of Crescas' God, there's nothing behind those manifestations. Nevertheless, it's a mark against Abrahamic impersonalism if it must label the very experiences that motivate many to adhere to Abrahamic religions as substantively deceptive.

\section{Objection 3}

At Mount Sinai, God didn't introduce Himself as the creator of the universe, but as 'The Lord your God who brought you out of the land of Egypt, from the house of bondage' (Exodus 20:2). Rabbi Yehudah HaLevy infers from this that the Jewish relationship with God, as presented by the Bible, is more personal than philosophical - we discover Him in personal and communal relationship rather than as the conclusion of a proof for His 
existence (HaLevy (1964), I.25, pp. 46-47). In fact, the entire Hebrew Bible is, in large part, a document of the covenantal relationship between a particular nation and God.

Louis Newman $(1991,95)$ points to biblical treatments of covenant, according to which a covenant - quiet unlike a contract - only makes sense in the context of a prior relationship. Moreover, parties to a contract are not committed to anything that isn't explicitly among the terms of the contract. Covenantal relationships, by contrast, are more open-ended. The people commit to obey God's voice, even beyond any specific injunction written in the Pentateuch. These duties arise 'not from the text of Torah, or even from the interpretations of that text, but from living in relationship with God' (ibid., 98).

God's capacity to take part in meaningful, dynamic, and interpersonal relationships seems central to the Bible's own presentation of the covenant at its heart. Impersonalism, one might think, cannot accommodate this Divine capacity. This presents a cost to any impersonalism committed to the veracity of scripture.

\section{Objection 4}

In the context of a careful analysis of multiple books of the Bible, Rabbi Heschel concludes that:

the fundamental experience of the prophet is a fellowship with the feelings of God, a sympathy with the divine pathos ... The prophet hears God's voice and feels His heart. He tries to impart the pathos of the message together with its logos.

(Heschel (2001), 31)

Moreover, Rabbi Heschel discovers that God's ethos is inseparable, in the Bible, from His pathos. That which is unjust is presented as equivalent to that which angers or even hurts God. That which is just is that in which God rejoices (ibid., 279).

Perhaps God's causal imprint on the world merely manifests as if $\mathrm{He}$ stands in a covenantal relationship. Perhaps the prophets merely impose the language of pathos upon the logos of their prophecy, for poetic effect. But such a wholesale rereading of the central narratives of the Bible, squeezing anything truly personal out of the covenantal relationship, and all pathos out of the prophetic moment, is to disfigure the biblical narrative beyond recognition.

To use the words of Alvin Plantinga, what remains of the biblical narrative, once God's personhood has been interpreted away, will be

something wholly drab, trivial, and insipid. It is not even a matter of throwing out the baby with the bathwater; it is, instead, throwing out the baby and keeping the tepid bathwater, at best a bland, unappetizing potion that is neither hot nor cold and at worst a nauseating brew, fit for neither man nor beast. (Plantinga (2000), 42)

\section{Objection 5}

According to Crescas, at least some biblical descriptions of God needn't be parried away. For example, God really does loves us. But Ryan Mullins (2020) raises a powerful concern. According to him, impassible love isn't really love. If Mullins is right, then Crescas would have to surrender this final biblical conception of the creator; resigning God's passionate love for Israel in the Book of Hosea and the Song of Songs to the same disfiguring re-reading he must already apply to the biblical presentation of covenant and prophecy. Why does Mullins think that impassible love isn't love? 
Love includes a desire for 'union with the beloved' (Mullins (2020), 41). Eleonore Stump suggests that the union in question requires personal presence and mutual closeness (Stump (2012), 109). Personal presence is, according to Stump, the consequence of joint attention. If loving somebody includes wanting union with them, and if union requires joint attention, an impassibilist God will get stuck. Joint attention requires causal interdependence. Moreover, the notion of any desire makes little sense for an impassible God, who is 'perfectly satisfied in Himself:

[D]esire satisfaction quite clearly entails change from having a desire to satisfying a desire. In order to avoid this problem, a classical theist might try to say that God analogically has desires. However, the idea of timelessly and immutably having a desire that is also timelessly and immutably satisfied does not sound like an analogical use of desire. Instead, it sounds incoherent ...

(Mullins (2020), 44-45)

Biblical talk of God's love will have to succumb, it seems, to the life-draining re-reading that the impersonalist anyway applies to the biblical presentation of covenant and prophecy. Having outlined these objections, let's turn to the personalist alternative.

\section{Personalism}

What we've come to see is that God cannot be fully personal if He isn't open to the sort of interactive relationship that requires a being to undergo change in response to the states and experiences of another. But a being cannot undergo change if that being is outside time. The only way to allow for a personal God therefore seems to require that God should be a temporal being; a being in time. This type of theology is known as open theism. (of course, placing God within time is going to raise various problems that Maimonides and Crescas sought to avoid. These problems will come back upon the adoption of open theism (see objection 3, in the next section of this article). But this merely helps to motivate the central antinomy of this article, as we recognize pressures forcing us to think of God both as personal and impersonal; as temporal and atemporal; as moved and unmoved. But, for a moment, let's put our concerns with open theism to one side. Let's instead try to get a better grasp of the view and its strengths.)

Open theists insist that God can be open to change even while being constantly perfect. Enter William Hasker, and his perfect watch:

A short while ago, it registered the time as five minutes after six o'clock, but now it registers twelve minutes after six. Clearly, this is a change in the watch. (Compare this watch with an 'immutable' watch that always registers 10:37, day in and day out) Is this a change for the better, suggesting a previous state of imperfection? Not at all ...Is it then a change for the worse, a decline from perfection? ... It is, in fact, an example of a change that is consistent with and/or required by a constant state of excellence.

(Hasker (1994), 132-133)

Perfection can allow for change, but only if the perfect being - like Hasker's watch - is located in time. A timeless God, by contrast, needn't change to keep up with the passage of time.

Hasker argues that there is a reason to situate a perfect God in time, since only if you do so can God grant human beings freedom; and, you might insist, we clearly do have free will. If God is somehow outside of time, and possesses the perfection of omniscience, then 
He must know all things from the vantage point of His eternal present. Our past, present, and future would all be present to Him. But, if our future is, so to speak, already present to God, then the future must already exist. ${ }^{22}$ If the future is already written, and God already knows it, then it seems as if we don't have the power to write our own future.

Maimonides tries to escape this problem with two claims: (1) God can know the future even though it doesn't exist and (2) God can know infallibly that something will happen without necessitating that it happen (Maimonides (2000), 3.20). Granted: human knowledge requires existing facts to be known and necessitates that what is known is true. But God's knowledge is different. Gersonides was unimpressed. If 'knowledge' is so radically equivocal that it behaves so differently in the case of the Divine, then we can have no sense of what we really mean when we say that God knows the future. This reconciliation between free will and timeless omniscience is at best a pyrrhic victory (Gersonides (1987-1999), vol. II, p. 79). ${ }^{23}$

Another option is to deny that we have libertarian freedom (namely, the sort of freedom that cannot be determined by forces external to the willing agent herself). This was the route that Crescas took (as did John Calvin and Mulla Sadra). Crescas insisted: although our actions are predetermined, we do have free will. He makes room for this combination of views by endorsing a compatibilist account of freedom. Freedom is the power to act in accordance with your preferences. It shouldn't matter to your freedom that those preferences were predetermined. ${ }^{24}$

What if you share the intuition that compatibilist freedom is a hollow counterfeit of libertarian freedom? Why would God reward you for doing good if you couldn't have done otherwise? Why would He punish you for sin if you had no ability to refrain? Crescas has various responses to these questions, but one can understand why a libertarian Jewish philosophy would be desirable.

To reconcile God's omnipotence, omniscience, and the human possession of libertarian free will, without the word games that Maimonides is accused of playing, Hasker endorses open theism. God is a temporal being. He decided to create a world and give people libertarian freedom. This decision entails that major parts of the future were left over for humans to shape. God knows everything there is to know, but regarding human choices, there is no future for Him to know. ${ }^{25}$ God has to wait upon the passage of time. Only a temporal God can give His creatures freedom in this way.

According to open theism, there's a sense in which 'God is a risk-taker' - that is to say, 'in expressing his love toward us', and granting us freedom, God 'opens himself up to the real possibility of failure and disappointment' (ibid.). God is aware of all possible eventualities and their likelihoods. At any point, God can temporarily rescind a person's free will, or otherwise interfere with the natural order. He can guarantee that His promises to the prophets will be realized by hook or by crook. But to grant us freedom was nevertheless to volunteer to be ignorant about aspects of the future. The God of open theism is a perfect but temporal being, as changeable as Hasker's clock. In the twentieth and twenty-first centuries, certain Jewish theologians seemed to move in the direction of open theism.

That the creation was a risk comes to the fore in the writing of Rabbi Sacks:

[B]y creating humans God was putting the entire future of creation at risk ... The real religious mystery, according to Judaism, is not our faith in God. It is God's faith in us ... God invests His hopes for the universe in this strange, refractory, cantankerous, ungrateful, and sometimes degenerate creature called Homo sapiens, part dust of the earth, part breath of God, whose behaviour disappoints and sometimes appals Him. Yet He never gives up.

(Sacks (2020), 5) 
Rabbi Heschel tells a plausible story as to why open theism must adopt a theology of pathos. Indifference, for a being who doesn't have to be indifferent, would be a terrible vice. 'The God of the philosophers', he complained, 'is all indifference, too sublime to possess a heart or to cast a glance at our world' (Heschel (1951), 244). But indifference is 'an evil' that renders one 'neutral, impartial, and not easily moved by the wrongs done to other people' (Heschel (2001), 364). The God of Greek philosophy had to be indifferent. ${ }^{26}$ The cause of causes had to be uncaused. But the God who grants humans freedom is a temporal being. He can shed indifference, and so He must. The God of Aristotle was an unmoved mover. The God of Rabbi Heschel is the 'most moved mover'. ${ }^{27}$

If God ever wants to intervene, in human history, He can. That God doesn't intervene more often is a source of pain and confusion (cf. Held (2013), 180). But ultimately, the open theist is bound to see the weight of responsibility for moral evil hanging, primarily, on the shoulders of man. We should not seek to shift 'the responsibility for man's plight from man to God' (Heschel (1951), 151). The same attitude is evidenced in the words of Rabbi Sacks:

When I first stood at Auschwitz-Birkenau the question that haunted me was not 'Where was God?' God was in the command 'You shall not murder.' God was in the words 'You shall not oppress the stranger.' God was saying to humanity, 'Your brother's blood is crying to Me from the ground.' God did not stop the first humans eating forbidden fruit. He did not stop Cain from committing murder. He did not stop the Egyptians enslaving the Israelites. God does not save us from ourselves. That, according to the Talmud, is why creating man was such a risk that the angels advised against it. The question that haunts me after the Holocaust, as it does today in this new age of chaos, is 'Where is man?'

(Sacks (2020), 7)

The God of Jewish open theism has logos, pathos, and ethos. ${ }^{28} \mathrm{He}$ is open to emotional sharing and joint attention. Prayer, on this picture, can be 'the touch of two selves' (Sacks (2000), 78). This theology owes more to the Hebrew Bible and the Talmud than it does to Aristotle and Athens. It escapes every objection we levelled against Maimonides and Crescas above. Sadly, as we shall see, it isn't free from problems of its own.

\section{Problems with personalism}

\section{Objection 1}

If God is omnipotent, then isn't He invulnerable? ${ }^{29}$ If God is invulnerable, then how can He be subject to suffering or disappointment?

Rabbi Heschel is alert to this concern. While discussing the Jewish tradition that God's presence, the Shekhinah, goes into exile with the Jewish people, he writes:

[T]here is an obvious contradiction between the belief in God's omnipotence and the belief that He, too, is in need of salvation. Perhaps the resolution is this: just as the Creator, whose glory fills the universe, contracted (tzimtzem) his Shekhinah between the staves of the Ark in order to reveal His words to Moses, so did God compress (tzimtzem) His Shekhinah into the history of Israel, so that He might be revealed to His chosen nation as they went into exile. 
Rabbi Heschel here appeals to the Kabbalistic doctrine of tzimtzum: the idea that God somehow reined in some of His power to make room for the creation of the universe. As Rabbi Held explains:

[Heschel's appeal to] the language of tzimtzum (self-contraction) suggests God's voluntary self-limitation ... It is almost as if God has a choice between exercising His omnipotence, thereby being revealed in glory rather than mercy; and surrendering His omnipotence, thereby potentially being revealed in His vulnerable and merciful presence. The key point here, at any rate, is ... the notion of self-imposed limits on God: 'Out of His participation in the suffering of the nation, God, as it were, takes her afflictions upon Himself.'

(Held (2013), 169-170, quoting Heschel (1962), 86)

Since the self-contraction is voluntary, God ultimately remains omnipotent throughout. He can, at any moment, return to His natural state of invulnerability. ${ }^{30}$ Accordingly, God's emotions differ from ours to the extent that His are always an expression of His will. Unlike our emotions, God's are always chosen (Heschel (2001), 363, 382). God's emotions are like a garment freely donned (ibid., 620-621), and freely discarded.

This theory gives rise to two questions.

1. Can an essentially omnipotent being truly will for temporary vulnerability?

2. Is voluntary suffering really suffering at all?

In order to give our second question an affirmative answer, Anastasia Scrutton (2011) presents three examples.

Her first is 'a woman who chooses to experience morning sickeness and later birth-pains in order to have a baby' (ibid., 159). I concede: she did choose (in a manner of speaking) to suffer, and her suffering is real, but once the choice had been made, she couldn't escape the pain. To be germane, we need an example of suffering that's compatable with the ability, at any time throughout the episode in question, to escape without cost. The pregnant woman, even if she got pregnant by choice, doesn't have that ability. She is not a relevant example.

Scrutton's second example is a martyr, 'tortured and executed because he won't relinquish his beliefs' (ibid.). This example seems more pertinent. It was logically, metaphysically, and nomologically possible for the martyr to renounce his faith, at any point. But Harry Frankfurt (1982) is right, I think, to appeal to a notion of 'volitional necessity':

There are occasions when a person realises that what he cares about matters to him not merely so much, but in such a way, that it is impossible for him to forbear from a certain course of action. It was presumably on such an occasion, for example, that Luther made his famous declaration: 'Here I stand; I can do no other.' An encounter with necessity of this sort characteristically affects a person less by impelling him into a certain course of action than by somehow making it apparent to him that every apparent alternative to that course is unthinkable.

(ibid., 263)

The martyr was volitionally compelled. Perhaps an omnipotent God can be volitionally compelled to suffer too, but it's not obvious that He can. Would a perfect being ever find itself in such a situation?

Scrutton's third example is a saintly individual who 
gives his wealth to the needy, stops working in the family business ... and passes over the opportunity of making a lucrative ... marriage. Dressed in rags and eating only leftovers he makes his way to a nearby leper colony where he embraces these social outcasts, and tenderly looks after them ... [H]e is granted the stigmata, which he bandages up to avoid self-aggrandizement ... Eventually, and foreseeably, he too contracts leprosy, but continues to lead a life of prayer and service to others, remaining tender, cheerful and faithful to the end of his life.

(Scrutton (2011), 159-160)

This man's suffering is certainly authentic. But note: many elements are not such that he can make them cease with immediete effect. Upon contracting leprosy, he has no way to halt the progress of the disease; nor can he wish his stigmata away (not that he'd want to). His poverty, however, might be different. Perhaps his situation allows him to call wealthy relatives, and escape. If so, then, unlike his leprosy and stigmata, I don't think that he would wear the pain of his poverty in a way that resembles the real pain of poverty.

According to Scrutton, God's voluntary suffering can be authentic. I remain unconvinced, but even if she's right, our other question stands. Can an essentially omnipotent being coherently will for the temporary suspension of His invulnerability?

A healthy person could one day become ill. Likewise, an omnipotent person could one day become weak. ${ }^{31}$ But you might think that a perfectly healthy person would be an essentially healthy person (since essentially good health is more perfect than contingent good health), this would render the person necessarily healthy, and that would rule out the very possibility of ill health. Likewise, if God is perfectly omnipotent, then He must be necessarily omnipotent, and thus the very possibility of suffering is precluded. ${ }^{32}$

In response, Scrutton avers: 'Surely... the idea that God cannot choose to be susceptible to things outside God's control is more of a threat to God's omnipotence than the idea that God can choose to undergo emotion' (ibid., 157). But that doesn't seem right. Gregory Thaumaturgus talks in terms of God's power to overcome His own nature. ${ }^{33}$ But the power to overcome one's own nature sounds no more coherent than the power to square a circle. To say that God can't do it isn't to limit Him, since squaring a circle isn't a thing to be done. The Mishna teaches that true might is the ability to conquer one's own dispositions and inclinations (Tractate Avot 4:1). True. But nothing can overcome its own metaphysical nature. To say that God can't do it, as with squaring a circle, isn't to limit God. It is of the nature of a nature not to be overcome.

Perhaps a personalist could agree with me that an impassible God cannot will Himself to be passible. Instead, she could argue that God must always have had an emotional and empathetic nature. Still, she might argue, this doesn't render God inherently vulnerable because God didn't have to create anything. He didn't have to create a world that might negatively affect Him. ${ }^{34}$ This response strikes me as hollow. To the extent that God could, even if only in principle, be hurt, are we really preserving perfect omnipotence? Perfect omnipotence isn't compatible even with potential vulnerability (because only necessary omnipotence counts as perfect). It seems to me that personalism simply rules out the claim that God is perfectly omnipotent. ${ }^{35}$

\section{Objection 2}

Xenophanes said:

If oxen and horses and lions had hands or could draw with hands and create works of art like those made by men, horses would draw pictures of gods like horses, and oxen 
of gods like oxen ...

(Freeman, 1952, fragments 15-16)

Rabbi Eliezer Berkowitz was shocked by the anthropomorphism of Rabbi Heschel's theology (Berkowitz, 1964). But Rabbi Berkowitz doesn't do justice to Rabbi Heschel's response.

Oxen would depict God in their image; a community of triangles would worship a triangular God. The fallacy of these statements is concealed in their glibness. Do oxen depict God? Are triangles capable of worship?

(Heschel (1955), 350)

Sophisticated theology recognizes that God defies discursive description. And yet, anthropopathism (unlike other forms of anthropomorphism) is justified to the extent that it plays upon the very faculties that drive us, unlike oxen and triangles, to seek God out and worship Him in the first place; namely, emotion.

An anonymous reviewer points out an equally powerful response to Xenophanes. It simply isn't true that we depict God as a man. We depict him as a person. By parity of reason (and if these animals were personal enough to develop a religious sensibility), horses and oxen wouldn't depict God as a horse or an ox, but as a person.

Nevertheless, there are religious experiences that do seem to undermine Rabbi Heschel. Indeed, Jewish mysticism is replete with reports of experiences that transcend the distinction between subject and object; experiences that present God, paradoxically, as beyond all description - even the description of personhood. Some Kabbalists took to describing God in terms of nothingness (Hebrew: Ayin); not because they denied the existence of God, but because of their conviction that no thing (i.e. no name, no description, no property) could ever qualify Him (Matt (1990)).

Hilary Putnam goes so far as to say that 'it is part of almost all religious forms of life to say that God ... is not properly conceptualizable by us' (Putnam (1997), 410).

This apophatic sensibility has biblical warrant. God's ways and thoughts are beyond us (Isaiah 55:8-9). He is incomparable to any other being (Exodus 15:11; I Kings 8:23; Psalm $35: 10 ; 86: 8)$. He tends to appear to the nation amidst a cloud, as if to signify that our grasp of Him can only ever be hazy and tenuous (Exodus 13:21-22; 16:10; Numbers 16:42; Leviticus 16:2; Deuteronomy 4:11; I Kings 8:10-12; Psalm 97:2).

It may not be crude anthropomorphism, but personalism still ignores the extent to which God transcends terrestrial categories.

\section{Objection 3}

As we already discussed, taking God out of time has some troubling side-effects. It seems to rob us of free will. In fact, Mullins (2016) cogently argues that the entire notion of a God, sitting outside time but somehow interacting with our temporal realm, is inconsistent with any known philosophical understanding of the nature of time. But what Mullins doesn't recognize, and what open theism in general struggles to respect is that, once faulty assumptions about time, and flawed objections about a temporal God, have been discarded, there are still compelling reasons to think that God must be unchanging and if God is both perfect and unchanging, then he must be impersonal and atemporal.

Why think that God must be unchanging? If causation and change are among the explananda for which God serves as explanans, then God Himself cannot be liable to causal manipulation or change. If God were among the things that can change and be causally reactive, then He would be one of the explananda rather than the explanans. God must 
therefore be an uncaused causer, and an unmoved mover. Open theism, with its changing temporal God, cannot allow God to serve, in this way, as the ultimate explanans.

A possible response, on behalf of the open theist, proceeds as follows: God need not be the direct explanation of all causation and change. Instead, God creates the material world, and continues to sustain it in being. But the particular contours of the events that transpire in the material world, post-creation, arise independently of God's causal activity (even if He's sustaining all of the causal agents in being). These changing events then provoke reactions from God. God, on this picture, remains the ultimate explanation and cause, but is Himself liable to change. ${ }^{36}$

I think this response can be countered. On this picture, God is the ultimate explanation of the changes that transpire in the created universe, but the created universe itself is the ultimate explanation of the changes that transpire in God. That would be to place God and the created universe on the same explanatory plane, which would, in turn, undermine the sense in which God is the ultimate explanans of all that goes on.

\section{Objection 4}

If Maimonides was concerned 'to reconcile the Bible with Aristotle's view of the universe and of man', Rabbi Heschel's concern was to discover 'the Biblical view of the universe and of man's position in it' (Heschel (1955), 22). In Rabbi Held's words, 'Heschel's challenge, as he sees it, is to rescue Jewish theology from the ravages of Greek thinking... and to allow the biblical and Rabbinic traditions to speak once again in their own voice' (Held (2013), 143). In this task, Rabbi Heschel was largely successful. He may have had trouble accommodating a handful of apophatic verses (as we saw in objection 2, above), but he does rescue the central message of the Bible from the clutches of impersonalism. Judaism, however, as Rabbi Heschel was aware, is not a purely biblical religion.

Open theism was first articulated by Protestant thinkers. It is characteristically Protestant to be led by Scripture. Indeed, compatibility with Scripture is one of the primary motivations for open theism. Rabbinic Judaism, by contrast, isn't Protestant. Despite lacking centralized clerical authority, Judaism always related to Scripture primarily through the lens of Rabbinic interpretation. The worry I'm trying to articulate here isn't about the internal consistency of open theology, but merely about its compatibility with Judaism.

A distinctively Jewish theory of revelation would see the will of God animating religious thought and practice, through progressive generations of Jewish life. To use the idiom with which Rabbi Heschel entitled his own study of revelation: the Heavenly Torah is refracted through the speculum of the generations (Heschel (1962); Idem (2006)). Revelation is unfolding. Accordingly, to the extent that Maimonides and Crescas have joined the great pantheon of Rabbinic thinkers, their thought has become part of the Torah. They are not infallible, but Revelation speaks through them too.

The challenge that Jewish theology faces isn't one of purging away alien elements, as Rabbi Heschel sought to do: its aliens have been naturalized. The challenge is to find a way to reconcile, as far as possible, the various conflicting threads of one cumulative revelation - the personal and the impersonal.

The Jewish philosopher, who believes that multiple thinkers and schools have been part of an unfolding process of revelation, within the Jewish tradition, recognizes that no single link in the chain (other than Scripture) is infallible. Accordingly, she will want to subject the work of those thinkers and schools to philosophical scrutiny in search of the most philosophically attractive way of finding a best fit between them. Indeed, that's what I seek to do vis-à-vis the vexed question of God's personhood in the next, and final, section of this article. 


\section{A middle way}

As Kant hoped to show in his antinomies, there can sometimes be equally strong arguments for and against a certain thesis. The question is, what to do when such a tension emerges? We have seen strong arguments against divine impersonalism. We've seen equally strong arguments against divine personalism. In this section, I argue that the tension is resolved upon the adoption of 'Hassidic Idealism'.

We've mentioned in passing the doctrine of tzimtzum - first articulated by Rabbi Isaac Luria. His student, Rabbi Hayyim Vital (1999), provides the first explicit account of the doctrine. He describes pre-creation. The infinite light of God was uniformly extended, leaving no space untouched; then there was a contraction of that light, leaving a circular void; finally, a thin line of light formed a channel between the inside and outside of the circle:

Within that [circular] empty place, He [then] emanated, created, formed, and made all the worlds - every one of them. Th[e penetrating] line is like a single narrow conduit through which the 'waters' of the supernal light of the Infinite spread and are drawn to the worlds that are in the empty space in that void.

(Vital (1999), 14)

Tyron Goldschmidt and I (Goldschmidt and Lebens (2020)) tease out an argument from these words. On our reading, Rabbi Vital's talk of light filling all of space is a metaphor. We're not really talking about light, or spatial extension. Rather, the talk of God's light getting in the way of creation is a metaphorical way of conveying that some divine attribute or other (call it perfection P), metaphorically rendered as 'light', makes creation impossible.

If God has $P$, then there is no logical space for creation; if there is no logical space for creation, then the creation cannot occur; but since creation does occur, God must have contracted $P$. To complete the analysis, we merely need to substitute $P$ for an actual Divine perfection and explain why that perfection leaves no room in logical space for creation.

Omnipotence could do the trick. Since God is omnipotent, He has a perfectly efficacious will. Consequently, any features of any object are wholly dependent upon the mind of God willing (or, at least, allowing) it to have those features. If God willed otherwise, things would be otherwise. But if all of the features of an object are wholly dependent upon a mind willing (or at least, allowing) it to have those features, then that object is an idea in that mind. So, if God is omnipotent, all objects are ideas in His mind.

This is an argument from theism to idealism. The only controversial premise (for a theist), is the following:

- if every feature of $x$ is wholly dependent upon a mind willing (or allowing) it to have those features, then $x$ is an idea in that mind.

You might have a number of counterexamples ready, but I refer readers to Goldschmidt and Lebens (2020) for further motivation and discussion. If the argument is sound, then God's omnipotence entails that He cannot create objects beyond His mind. And thus, either (a) God relinquishes or contracts His omnipotence, to make room for creation; or (b) the creation doesn't take place outside God's mind.

Option (a) requires God to give up, even if only for the duration of the existence of the universe, His omnipotence. But we've already discussed the troubles that emerge for voluntarily suspended perfect omnipotence. 
Alternatively, many Kabbalists, especially within the Hassidic movement, endorse (b). A perfect God is self-sufficient. He doesn't want to create a world outside Himself, since He has no wants, and no such world could exist. But He can tell Himself a story in which He imagines His creating a world. The desire to do so is self-contained within His selfsufficient being. He simply wants to express Himself. In fact, it's not really a desire at all, it's merely His nature to express Himself. This He does in His timeless eternity.

God didn't contract His omnipotence to create a world outside His mind. That's not possible. Instead, He timelessly creates a world that appears to be outside His mind, but which, in actual fact, has been in His mind all along. This is Hassidic Idealism.

If God imagines Himself as a character in the story that He imagines, and if, in the story, He is the creator of all that exists outside His mind, then, in the story, it must be true that He contracted his omnipotence. But of course, this is just a story. God in actual fact is immutable. He never changes. He never contracts. He just imagines that He does, and thereby creates an imaginary world. What's true for us, on the whole, is simply what's true in the story that God imagines. What's true for God, by contrast, is what's true outside the story. Within the story, it's true to say that tzimtzum occurred; our physical world exists, created ex nihilo. From God's perspective, by contrast, tzimtzum is just a story. Our world is just an idea.

When the Bible describes God's omnipotence, ${ }^{37}$ it's talking about God qua author, outside the story. When Maimonides or Crescas describe a totally impassible God, they too describe God outside the story. But when Maimonides says that God merely manifests as having emotions, he fails to recognize that if that's how God manifests, then that's how He really truly is, qua character in His story.

Religious experiences of a second-personal nature may well be experiences of God qua character in His own story. These are encounters, within the story of the world, and as real as the world itself, between two persons in that world. Religious experiences of an impersonal nature, by contrast, may give a person a glimpse of God beyond the story.

In our world - on this side of tzimtzum - God is a person who engages in covenantal relations. He shares His pathos with prophets and grants us libertarian freedom. This is true even if there exists a perspective, beyond our ken - on the other side of the contraction - in which it's true to say that we're not free at all, but merely characters in a Heavenly tale.

You might think that we haven't really given weight to God's personhood if we only allow it to exist on this side of the illusion of creation. Surely, it's still the case, even for Hassidic idealism, that God, in actual fact, has no empathy or love for us because $\mathrm{He}$ is impassible and, from His point of view, we're not even real. But there are two responses to this concern.

First: there is a type of love and empathy that one can feel for a fictional creation. Tolstoy was said to cry upon realizing how Anna Karenina's life would end. So, even beyond the veil of tzimtzum, where we can no longer talk about interpersonal relationships, we can still talk about love and empathy.

Second: Hassidic Idealism stratifies reality into two levels - there's what's true within the image that God imagines, and there's what's true beyond it. Even if we are imaginary from God's transcendent perspective, and God is impassible, it's also the case that we are real within the story in which we live, and God is temporal in that story too, and, in that story, we have a relationship with Him, and He loves us. All of those claims are as true as the very claim that you exist as a person of flesh and blood. That should be enough for us!

Beyond the story, God is immutable and eternal, eternally telling our story. Inside the story, He swims alongside us in the flow of time. Beyond the story, a perfect God lives in self-sufficient bliss. Like the God of Crescas, He possesses logos, pathos, and ethos, but is impassible. He cannot and need not enter into personal relations. For that reason, He isn't 
a person, even if $\mathrm{He}$ is a mind. ${ }^{38}$ Accordingly, it will be difficult for the Hassidic idealist to maintain the robust apophaticism of Maimonides, even when talking about God in His transcendence. God in His transcendence might not be a person, but this is only because God in His timelessness and in His ontological solitude cannot enter into interpersonal relations with temporal being like us. But, in order to imagine our world into being, He must, at least, be a mind. That's the sort of substantial theological assertion from which Maimonides would recoil. Nevertheless, the Hassidic Idealist maintains, recoil or not, that beyond the story of the world, even though God is not a person, He is a mind.

Alternatively, there may be reasons for thinking that beings within a story would have certain epistemic and linguistic constraints that systematically impede their attempts to describe the reality beyond their story (much like brains in a vat, according to Hilary Putnam (1982), are unable to say truly that they are brains in a vat). On this suggestion, our talk of God, beyond the story, being a mind that imagines us into being, is at best a sort of illuminating falsehood, aimed at gesturing towards something beyond our grasp (like the false but illuminating utterances of Putnam's brains in vats, stating falsely, 'I'm a brain in vat', while gesturing towards a truth that they cannot articulate; see Lebens (2020), §1.7.1).

God within the story is a person of tremendous power, who lovingly creates lesser people, like us, with whom to commune. Beyond the story of our world, God is - if we follow Crescas - a non-personal mind, and - if we follow Maimonides - He isn't even that. ${ }^{39}$

\section{Notes}

1. This terminology is ubiquitous, for example, throughout (Heschel (2001)).

2. Nicomachean Ethics I.13, De Anima III.11.

3. This statement needs to be qualified. As Wittgenstein pointed out, we do say that a dog is afraid his master will beat him' - which indicates a future-oriented preference. But we don't say that 'he is afraid his master will beat him to-morrow' (Wittgenstein (2001), §650, p. $140^{\mathrm{e}}$ ). That's to say, there is some sort of fine-grained futureorientation that seems to be specific to persons. Thanks to an anonymous referee.

4. This needn't imply that only self-legislating beings are ends in themselves.

5. This isn't to say that autistic people lack empathy even if empathy is sometimes somewhat harder for them to achieve (Hobson (2005), 197).

6. You might think, along with Ariel Meirav (in correspondence), that the receptivity of patienthood is 'a perfection rather than an imperfection'. I take it that the Maimonidean response asserts: only a being impervious to change and patienthood can serve as the ultimate explanation of change and causal processes. So even if patienthood has its benefits. God can't be a patient.

7. Thank you to an anonymous reviewer for pointing me to McCabe.

8. Ariel Meirav, in correspondence, rightly demurs. When I say that 'green is a colour' the syntax of my statement in no way implies that green is composite. But as I go on to explain, the type of simplicity that God has isn't merely mereological. By transcending all categories, God cannot have any properties, let alone a multiplicity of them.

9. See his introduction to Chapter 10 of Tractate Sanhedrin, in his commentary to the Mishna.

10. Thanks to an anonymous reviewer for this suggestion.

11. An anonymous reviewer rightly points out that this distinction, between an attribute and a property, needs spelling out. How can there be many of the former and only one of the latter? Here's my response, on behalf of Crescas:

Each predicate that truly applies to $x$ corresponds to what I'm calling an attribute. But a property, by contrast, is the universal that attaches to a particular and makes any number of predications true. For example, being square is one property, which will make many predications true. When $x$ is square it follows that $x$ is a four-sided regular polygon, $x$ has four right-angled corners, and $x$ counts as a rhombus with a right vertex angle. All of these predications are made true by the one single property of squareness instantiated by $x$. I would say, therefore, that $x$ has these multiple attributes in virtue of this one property. An attribute is something like an aspect of a property. 
According to Wolfson, 'Crescas maintains that all the [Divine] attributes are mental modifications of the single attribute of Goodness' (Wolfson (1916), 205). Using the terminology that I've introduced I would rather say that the multiple divine attributes correspond to different ways of thinking about the property of God's goodness. Indeed, I fear that Wolfson's analysis of Crescas, in general, fails to recognize the extent to which Crescas's attributes are supposed to be an ontologically free lunch, bolted on to a fundamental ontology of properties.

12. Given what I've argued in note 11 , we would normally say that the attributes of $x$ correspond to the multiple aspects of the properties of $x$. But God is a limiting case, for Crescas, because God is identical to His only property. Accordingly, attributes of God will be aspects of God's essence, but see the following note.

13. God is prior to any predicate or concept. Accordingly, God isn't somehow conceptually composed or complex, while being ontologically simple. Instead, we can, so to speak, use God to give meaning to any number of predicates, so long as God stands as the last member in a sequence of increasing intensity of resemblance in a given respect. These respects of resemblance, or aspects of God, amount to His multiple attributes.

14. In correspondence, Ariel Meirav suggests that, in the context of someone we love suffering, it seems that a failure to suffer 'would imply that things aren't right with God'. I imagine that Crescas would respond in terms of the requirement that the explanation of causation and change must be, itself, impervious to causation and change. Accordingly, our emotional states cannot act upon God. The joy of His overflowing love cannot be disturbed by the emotional states of those He loves.

15. You may worry, along with Aaron Segal (in correspondence), that this renders Divine 'knowledge' so radically different from human 'knowledge' that there's no continuity of meaning between the two terms. Regarding that worry, see Rosalyn Weiss' footnote 54 (Crescas (2018), 137-138).

16. You might think that your freedom is impaired if God's knowledge of your actions is what brings your actions into being, but see Lebens (2020), \$4.2.

17. This doesn't seem to be the route that Crescas would take. Like Gersonides, Crescas seems to think that God is implicated in the passage of time (Wolfson (1916), 182).

18. In correspondence, Ryan Mullins worries: the God of Crescas is uncomfortably similar to a psychopath. Psychopaths apparently manage to possess the cognitive dimensions of empathy, but not the affective dimensions. But, quite unlike a psychopath, the God of Crescas holds your emotions directly in his gaze and feels them, even if He doesn't feel them as His own. God's empathy does have an affective dimension.

19. Nagasawa argues, God's omniscience doesn't demand that He know what it's like to be me (Nagasawa (2008), 33-35). But I see no obstacle in the way of Crescas's God meeting this demand. There are emotions which he can't feel as His own, but He can still know what it feels like for others to feel them. He can recognize them in the face of another. More on this later.

20. An anonymous reviewer raises a powerful objection to this paragraph. 'If Tolstoy writes a story about Cantor and his discoveries', my reviewer wants to know whether Tolstoy must 'really understand these discoveries'. This issue deserves more attention than I can give in this article. But what I can say should suffice for now. My provisional response is this: an author doesn't have to understand everything that occurs within her story. Tolstoy might not know exactly how his fictional representation of Cantor proved that the real numbers are more numerous than the natural numbers, but it still seems right to insist that Tolstoy would know exactly how his fictional Cantor felt about the discovery. It is the phenomenal states of an author's characters that seem to be especially transparent to an author.

21. A doctrine with deep biblical roots: e.g., Deuteronomy 29:29; Jeremiah 23:24; Psalm 139:12; Job 28:24, 37:16. 22. Mullins (2016, ch. 3) explains that the first proponents of God's timeless eternity were presentists. What they mean when they say that all times are present to God isn't that all times exist, but that all times are somehow represented or known. Even so, to the extent that the future is already represented or known, the worry I develop remains, even if talk of existence is deceptive.

23. Indeed, it was Gersonides and his critique of Maimonidean apophaticism that inspired Crescas's account of religious language.

24. Some people define libertarian freedom in terms of the ability to do otherwise. But this isn't sufficient for libertarianism. In correspondence, Ryan Mullins informs me of a 'sneaky' tactic that allowed some Calvinists to affirm our ability to act otherwise. 'You could have done otherwise if God had caused you to do otherwise.' Likewise, a Lewisian will say that you could have done otherwise, even though your actions were causally determined, so long as you have counterparts in other possible worlds that do otherwise. But clearly, this isn't what a libertarian means by 'the ability to do otherwise'! Libertarians appeal to a form of freedom that cannot be determined by forces external to the agent. Thanks to an anonymous reviewer for useful comments on this topic. 25. Key elements of this view were foreshadowed by Gersonides (1987-1999, vol. II, 3:4). Note, however, that Gersonides was committed to a God who was resolutely impassible, and in no ways personal. Indeed, Gersonides is something of a midway point between Crescas and Maimonides. On the one hand, his God is as impersonal as the God of Maimonides - logos, without pathos. On the other hand, his God is implicated in 
time (which anticipates open theism), and his philosophy of religious language was the immediate inspiration for Crescas.

26. McCabe would clearly insist that God's lack of empathy doesn't entail callousness. But 'indifferent' does seem like an apt predicate. A rock on the beach is neither empathetic nor callous. But it does seem to be indifferent. So too the God of many medieval theologians.

27. This phrase was used to describe Rabbi Heschel's theology in (Rothschild (1959)).

28. I don't think that Rabbi Sacks was a straightforward open theist. I have reason to believe that he would probably have adopted something like the Hassidic middle path that I advocate in the final section of this article. For evidence to that end, see Sacks (1973). Rabbi Heschel, by contrast, seems to have been more resolute in his open theism (Held (2013), 237 n. 57, 145).

29. For the biblical evidence of God's omnipotence, see: Genesis 18:14; Jeremiah 32:17; 32:27; Job 42:2

30. Compare this with Swinburne's treatment of God's creating a stone too heavy for him to lift (Swinburne (2016), 166-168).

31. Again, see Swinburne (2016), 166-168.

32. Indeed, for this reason, I would argue that Swinburne's God (see the previous two notes) is not perfectly omnipotent.

33. See Mozley (1926), 64.

34. Thanks to Ryan Mullins for this suggestion.

35. Thanks to an anonymous reviewer for helpful comments on a previous draft of this section.

36. This response was put to me by an anonymous reviewer.

37. See note 29.

38. When I argued in Lebens (forthcoming) and implied in Lebens (2020) that God, outside the story, is a person, I wasn't operating with a different theology. I was merely operating with a different (and I would now say incomplete) conception of personhood. Outside the story, God is a mind (if, indeed, we can say things about Him at all). He may even be a very empathetic mind, with many characteristics of personhood. But, for reasons we've discussed, He doesn't meet all of the criteria for personhood as they were set out at the start of this article. Inside the story, by contrast, He is unambiguously a person.

39. Thanks to Ariel Meirav, Ryan Mullins, Aaron Segal, Danny Statman, Eleonore Stump, and Mohammad Saleh Zarepour, in addition to two anonymous reviewers. Thanks also to the Drisha Institute for Jewish Education where I first presented some of these ideas. This article is dedicated to the memory of my teacher, Rabbi Lord Jonathan Sacks זצוק.ל.

\section{References}

Aquinas T (2007) Summa Theologica. New York: Cosimo Classics.

Aristotle (2009) The Nicomachean Ethics. Oxford: Oxford University Press.

Augustine (1972) City of God. London: Penguin Books.

Berkowitz E (1964) Dr. A. J. Heschel's theology of pathos. Tradition: A Journal of Orthodox Jewish Thought 6, 67-104.

Berman L (1980) Maimonides on the fall of man. AJS Review 5, 1-15.

Crescas H (2018) Light of the Lord (Or Hashem). Oxford: Oxford University Press.

Fox M (1990) Interpreting Maimonides: Studies in Methodology, Metaphysics, and Moral Philosophy. Chicago: University of Chicago Press.

Frankfurt H (1982) The importance of what we care about. Synthese 53, 257-272.

Freeman K (1952) Ancilla to the Pre-Socratic Philosophers. Oxford: Oxford University Press.

Gersonides L (1987-1999) The Wars of the Lord. Philadelphia: The Jewish Publication Society.

Goldschmidt T and Lebens S (2020) Divine contractions: how theism gives birth to idealism. Religious Studies 56, 509-524.

HaLevy Y (1964) The Kuzari: In Defense of the Despised Faith. New York: Schocken Books.

Harvey WZ (1986) Ethics and Meta-Ethics, Aesthetics and Meta-Aesthetics in Maimonides. In Pines S and Yovel Y (eds), Maimonides and Philosophy. Dordrecht: Martinus Nijhoff, pp. 131-138.

Hasker W (1994) A Philosophical Perspective. In Pinnock CH et al., The Openness of God: A Biblical Challenge to the Traditional Understanding of God. Downers Grove, IL: InterVarsity Press, pp. 126-154.

Held S (2013) Abraham Joshua Heschel: The Call of Transcendence. Bloomington and Indianapolis: Indiana University Press.

Heschel AJ (1951) Man is Not Alone. New York: Farrar, Straus \& Young.

Heschel AJ (1955) God in Search of Man: A Philosophy of Judaism. New York, NY: Farrar, Straus \& Giroux.

Heschel AJ (1962) Torah min ha-shamayim be-aspaklaryah shel ha-dorot. New York: Soncino.

Heschel AJ (2001) The Prophets. New York: Harper Perennial. 
Heschel AJ (2006) Heavenly Torah: As Refracted through the Generations. New York: Bloomsbury Academic.

Hobson RP (2005) What Puts the Jointness into Joint Attention? In Eilan N, Hoerl C, McCormack T and Roessler J (eds), Joint Attention: Communication and Other Minds: Issues in Philosophy and Psychology. Oxford: Oxford University Press, pp. 185-204.

Hursthouse R (1999) On Virtue Ethics. Oxford: Oxford University Press.

Jackson F (1982) Epiphenomenal qualia. The Philosophical Quarterly 32, 127-136.

Kant I (1998) Groundwork of the Metaphysics of Morals (Grundlegung zur Metaphysik der Sitten). Cambridge: Cambridge University Press.

Kant I (2010) Anthropology from a Pragmatic Point of View. In Louden R and Zöller G (eds), Anthropology, History, and Education: Cambridge Edition of the Works of Immanuel Kant. Cambridge: Cambridge University Press, pp. 227-242.

Korsgaard CM (1996) The Sources of Normativity. Cambridge: Cambridge University Press.

Lebens S (2020) The Principles of Judaism. Oxford: Oxford University Press.

Lebens S (forthcoming) Is God a Person? Neo-Maimonidean Perspectives. In Gasser G and Kittle S (eds), The Divine Nature: Personal and A-Personal Perspectives. New York and London: Routledge.

Locke J (1997) An Essay Concerning Human Understanding. London: Penguin Books.

Maimonides M (2000) The Guide for the Perplexed. Mineola, NY: Dover Publications.

Makin S (2019) Mania may be a mental illness in its own right. Scientific American, 1 March.

Marr R (2011) The neural bases of social cognition and story comprehension. Annual Review of Psychology 62, 103-134.

Matt DC (1990) Ayin: The Concept of Nothingness in Jewish Mysticism. In Foreman RKC (ed.), The Problem of Pure Consciousness: Mysticism and Philosophy. New York and Oxford: Oxford University Press, pp. 121-161.

McCabe H (1985) The involvement of God. New Blackfriars 66, 464-476.

Moll H and Meltzoff AN (2012) Joint attention as the fundamental basis of understanding perspectives. In Seemann A (ed.), Joint Attention: New Developments in Psychology, Philosophy of Mind, and Social Neuroscience. Cambridge, MA: MIT Press, pp. 393-413.

Mozley JK (1926) The Impassibility of God: A Survey of Christian Thought. Cambridge: Cambridge University Press. Mullins RT (2016) The end of the timeless God. Oxford: Oxford University Press.

Mullins RT (2020) God and Emotion. Cambridge: Cambridge University Press.

Nagasawa Y (2008) God and Phenomenal Consciousness: A Novel Approach to Knowledge Arguments. Cambridge: Cambridge University Press.

Newman LE (1991) Covenant and contract: a framework for the analysis of Jewish ethics. Journal of Law and Religion 9, 89-112.

Oatley K (2008) The mind's flight simulator. The Psychologist 21, 1030-1032.

Plantinga A (2000) Warranted Christian Belief. Oxford: Oxford University Press.

Putnam H (1982) Reason, Truth, and History. Cambridge: Cambridge University Press.

Putnam H (1997) On negative theology. Faith and Philosophy 14, 407-422.

Ramachandran V and Oberman L (2006) Broken mirrors: a theory of autism. Scientific American 64, 62-69.

Rochat P (2014) Origins of Possession: Owning and Sharing in Development. Cambridge: Cambridge University Press.

Rochat P and Striano T (1999) Social-cognitive development in the first year. In Rochat P (ed.), Early Social Cognition: Understanding Others in the First Months of Life. Hillsdale, NJ: Erlbaum, pp. 3-34.

Rothschild FA (1959) Introduction. In Heschel AJ (ed.), Between God and Man: An Interpretation of Judiasm from the Writings of Abraham J. Heschel. New York: Free Press, pp. 7-32.

Rynhold D (2021) Maimonides on the Nature of Good and Evil. In Frank D and Segal A (eds), Maimonides' Guide of the Perplexed: A Critical Guide. Cambridge: Cambridge University Press.

Sacks J (1973) Alienation and faith. Tradition 13, 137-162.

Sacks J (2000) Celebrating Life: Finding Happiness in Unexpected Places. London: Fount.

Sacks J (2020) Judaism's Life-Changing Ideas: A Weekly Reading of the Bible. Jerusalem: Magid Books and Oxford University Press.

Scrutton A (2011) Thinking Through Feeling: God, Emotion and Passibility. New York and London: Bloomsbury Academic.

Searle J (1990) Collective intentions and actions. In Cohen P, Morgan J and Pollack ME (eds), Intentions in Communication. Cambridge, MA: MIT Press, pp. 401-416.

Searle J (1995) The Construction of Social Reality. Cambridge: The Free Press.

Shoemaker S (2015) Persistence and properties. Journal of the American Philosophical Association 1, 433-448.

Singer P (1993) Practical Ethics, 2nd edn, Cambridge: Cambridge University Press.

Soloveitchik J (2016) Maimonides: Between Philosophy and Halakhah: Rabbi Joseph B. Soloveitchik's Lectures on The Guide of the Perplexed. Jerusalem and New York: Ktav/Urim.

Sperber D and Wilson D (1986) Relevance: Communication and Cognition. Oxford: Blackwell. 
Stokes PRA, et al. (2020) Unipolar mania: identification and characterisation of cases in France and the United Kingdom. Journal of Affective Disorders 263, 228-235.

Stump E (2012) Wandering in Darkness. Oxford: Oxford University Press.

Swinburne R (2016) The Coherence of Theism, 2nd edn, Oxford: Oxford University Press.

Vital C (1999) The Tree of Life: Chayyim Vital's Introduction to the Kabbalah of Issac Luria: The Palace of Adam Kadmon. Northvale, NJ and Jerusalem: Jason Aronson.

Wittgenstein L (2001) Philosophical Investigations. 50th Anniversary Commemorative ed. Malden, MA: Blackwell Publishing.

Wolfson HA (1916) Crescas on the problem of divine attributes (Part II). The Jewish Quarterly Review 7, 175-221. Young K and Saver JL (2001) The neurology of narrative. Interdisciplinary Perspectives 30, 72-84.

Zagzebski L (2013) Omnisubjectivity: A Defense of a Divine Attribute. Milwaukee: Marquette University Press.

Zahavi D (2015) You, me, and we: the sharing of emotional experiences. Journal of Consciousness Studies 22, 84-101.

Cite this article: Lebens S (2022). Is God a person? Maimonides, Crescas, and beyond. Religious Studies 58, S34-S60. https://doi.org/10.1017/S0034412521000299 